\title{
Expression of Target Gene Hsp 70 and Membrane Stability Determine Heat Tolerance in Chili Pepper
}

\author{
Magaji G. Usman \\ Department of Crop Science, Faculty of Agriculture, Universiti Putra Malaysia, 43400 UPM, \\ Serdang, Selangor, Malaysia \\ Mohd Y. Rafii ${ }^{1}$ and Mohd Razi Ismail \\ Department of Crop Science, Faculty of Agriculture, and the Institute of Tropical Agriculture, \\ Universiti Putra Malaysia, 43400 UPM, Serdang, Selangor, Malaysia \\ Mohammad Abdul Malek \\ Institute of Tropical Agriculture, Universiti Putra Malaysia, 43400 UPM, Serdang, Selangor, \\ Malaysia; and the Bangladesh Institute of Nuclear Agriculture, Mymensingh-2202, Bangladesh \\ Mohammad Abdul Latif \\ Department of Crop Science, Faculty of Agriculture, Universiti Putra Malaysia, 43400 UPM, Serdang, \\ Selangor, Malaysia; and the Bangladesh Rice Research Institute, Gazipur-1701, Bangladesh
}

\begin{abstract}
AdDITIONAL INDEX wORDs. Capsicum annuum, stress-responsive protein, electrolyte leakage, heat stress, thermal tolerance
Abstract. Experiments were carried out to study the mechanisms for heat tolerance in chili pepper (Capsicum annuиm). To assess these mechanisms, six genotypes were evaluated for cellular membrane thermostability (CMT) and for $H S P 70$ gene expression. The plants were grown in an experimental plant growth chamber. The mean value of CMT indicates that membrane integrity was not damaged by the high temperature treatment $\left(50{ }^{\circ} \mathrm{C}\right)$ in most of the genotypes. The genotypes were classified as follows: heat-tolerant (greater than $60 \%)$, moderately tolerant $(30 \%$ to $60 \%$ ), and susceptible (less than $30 \%$ ). The heat-tolerant plants recorded the highest CMTs at $89.27 \%, 88.03 \%$, and 85.10\% for AVPP0702, AVPP0116, and AVPP9905, respectively, which might be the reason for the change in their cell membrane thermostability. AVPP9703 and AVPP0002 showed CMTs of $15.87 \%$ and $18.43 \%$, which might indicate their sensitivity to heat stress. Heat shock protein $70 \mathrm{kDa}$ was identified and found to be differentially expressed under the heat stress. Under heat stress, significantly increased levels of the $H S P 70$ gene were detected after $2 \mathrm{~h}$ of temperature treatment at $42^{\circ} \mathrm{C}$, which indicated that this gene is quickly and sharply induced by heat shock. This was true for all genotypes tested, which were significantly up-regulated by more than 36.9-, 7.10-, 3.87-, and 3-fold for AVPP0702, AVPP0116, AVPP0002, and AVPP9703, respectively. The HSP70 gene was found to be significantly down-regulated under heat stress in 'Kulai'. AVPP0702, AVPP9905, and AVPP0116 could be considered as heat-tolerant genotypes, whereas 'Kulai' and AVPP9703 were found to be heat-sensitive genotypes in this investigation.
\end{abstract}

Chili pepper is widely cultivated, primarily as a spice crop (Dahal et al., 2006). It also is cultivated for fresh vegetable (Ajjapplavara et al., 2010) and postharvest processing markets (Acedo, 2010). In other words, some peppers are grown mainly for postharvest processing such as processing peppers into paste for commercial purposes. The optimum day temperatures for chili pepper growth ranges from 20 to $30{ }^{\circ} \mathrm{C}$ (Dahal et al., 2006), and temperature and other abiotic stresses are clearly limiting factors for the growth and development of this crop. Indeed, stresses resulting from high temperature can be harmful to all phases of plant development, and global climate change is thought to cause extreme environmental fluctuations in most agricultural regions (Sood et al., 2009). Temperature increase resulting from changing climatic condition is a serious threat

Received for publication 18 Nov. 2014. Accepted for publication 5 Dec. 2014 We are grateful to the Ministry of Education, Malaysia, for adequate funding of the research through the Fundamental Research Grant Scheme (FRGS/1/2012 STWN03/UPM/02/2: 07-01-13-1240FR). We also acknowledge Asian Vegetable Research and Development Centre, Taiwan, for the supply of seeds. Gratitude also goes to Mojtaba Ghasemi for his constructive criticism.

${ }^{1}$ Corresponding author. E-mail: mrafii@upm.edu.my.
(Jones et al., 1999) that affects crop production. Heat stress occurs when temperatures are high enough to cause irreversible damage to plant function, affecting various physiological and metabolic processes in plants, and is detrimental in terms of growth and productivity (Ahmed and Hassan, 2011; Hall, 2010). Cell membrane thermostability is a phenotypic parameter used in measuring electrolyte leakage from leaves of plants at different temperatures. Several studies have indicated that CMT is effective in detecting genetic differences with regard to heat tolerance among several crops (Islam et al., 2014; Kumar et al., 2012; Yeh and Hsu, 2004). Heat stress leads to drastic changes in the cell membrane stability and ultimately influences the sensors present in the membrane (Suzuki and Mittler, 2006). Therefore, understanding how plants respond to stress is an important area of research.

Heat shock proteins (HSPs), or stress proteins, are highly conserved and present in all plants and animals. Previous results revealed that most HSPs serve as molecular chaperones (Bukau et al., 2006; Pratt et al., 2001). These proteins play an important role in protein stabilization such as assembling of multiprotein complexes, folding or unfolding of proteins, transport or sorting of proteins into correct compartments at the subcellular level, 
control of cell cycle, and signaling and cell protection against stress or apoptosis (Kuwabara and Imai, 2009). HSPs are known to be connected to the ability of the plant to respond to physiological stress, through biosynthesis, accumulation, or reduction (Wang et al., 2004). In plants, the expression pattern of a number of genes modulated in response to various acute environmental changes, resulting in an altered pattern result in altered biochemical and physiological activities of the cell and the developmental processes of the organism (Knight, 2010). When cells are exposed to various stress conditions such as heat stress, heat shock factors (HSFs) residing in the cytosol dissociate from HSPs (e.g., HSP70) are activated and undergo trimerization. These HSF trimers are phosphorylated and translocated to the nucleus where they bind to the heat shock elements, which are located in the promoter region of the HSP genes. HSP mRNA is then transcribed and translated, which leads to increased levels of HSPs in the cytosol. As such, these factors function as chaperones for denatured proteins and also assist in the translocation and/or degradation of damaged proteins (Young, 2010).

Within the diverse HSP family, HSP70 is the most widely studied member and a highly conserved $70-\mathrm{kDa}$ protein that plays a key role in the stress response in plants (Efeoğlu, 2009). In addition to roles in heat stress, HSPs are essential components of cells and developmental processes under normal physiological conditions. All organisms express HSPs belonging to the HSP70 family with molecular weights between 68 and $78 \mathrm{kDa}$ (Lindquist, 1986). Of the HSP families, the HSP70 family has a strong correlation with resistance to heat, either permanent or transient (Hightower, 1991). HSP70 generally functions as a molecular chaperone; i.e., preventing the accumulation of and assisting in the re-folding of proteins under the conditions of stress. The role of HSP70 in relation to heat tolerance has been reported in several crop plants such as soybean [Glycine max (Ortiz and Cardemil, 2001)], wheat [Triticum aestivum (Duan et al., 2011)], tomato [Solanum lycopersicum (Fender and O'Connell, 1989)], and creeping bentgrass [Agrostis palustris (Ye et al., 2012)]. HSP70 also plays a regulatory role in the stress-associated expression of other genes (Lee and Schöffl, 1996). However, research on HSPs in chili pepper is quite insufficient. The topic of enhancing protection mechanisms (including HSPs and CMT) to induce heat resistance is very interesting, and research in this area has many repercussions for the understanding of heat stress responses. This study therefore aimed at analyzing the changes in CMT and expression of HSP genes in chili pepper under heat stress. The response mechanism of chili pepper to elevated temperature would aid in the development of genotypes that perform better under heat stress. However, the mechanism for heat tolerance using the electrolyte leakage and the expression of HSPs in chili pepper needs to be further exploited to identify heat-tolerant lines for the development of high-yielding heattolerant hybrid cultivars.

\section{Materials and Methods}

Planting materials. Chili pepper genotypes (AVPP0702, AVPP0116, AVPP9905, AVPP9703, AVPP0002, and 'Kulai') were grown under controlled conditions $\left[28{ }^{\circ} \mathrm{C}, 16 / 8 \mathrm{~h}\right.$ (light/ dark)] to study the membrane stability and expression of HSP70 gene under heat stress. Seeds were collected from AVDRCThe World Vegetable Center [Tainan, Taiwan (Table 1)].
AVPP0702, AVPP0116, and AVPP9905 were selected because of their thermo tolerance (AVRDC, unpublished data; Usman et al., 2014a). 'Kulai' is a local cultivar cultivated in Malaysia. It was included in the trial as a control and its performance was compared with the AVRDC-introduced cultivars. The chili pepper genotypes were first evaluated to study their morphological, physiological, and biochemical characteristics at the Agrotechnology site, Institute of Tropical Agriculture, Universiti Putra Malaysia, Serdang, Selangor. Characteristics assessed are represented in Table 2.

Evaluation of CELl Membrane thermostability. Samples of similar leaf sizes were selected $60 \mathrm{~d}$ after sowing. Each sample for assay consisted of a paired set [control (C) and treatment $(\mathrm{T})$ ] of six leaf disks, each $1.3 \mathrm{~cm}^{2}$, using a leaf puncher $13 \mathrm{~mm}$ in diameter. The disks were cut from five fully expanded third or fourth leaves from the top of the stem axis from each genotype. Samples were replicated three times each. Before the assay, the paired set of leaf disks were placed in two separate test tubes $(50 \mathrm{~mL})$ and washed thoroughly with four exchanges of deionized water, $10 \mathrm{~mL}$ each time, to remove electrolytes adhering to the cut surface of the leaf discs. After the final wash, both sets of test tubes were filled with $10 \mathrm{~mL}$ deionized water and sealed with aluminum foil to avoid evaporation. The $\mathrm{T}$ set of the test tubes was incubated for $20 \mathrm{~min}$ at $50{ }^{\circ} \mathrm{C}$ in a temperature-controlled water bath (Oilbaths Model ONE 7; Memmert, Frankfurt, Germany); the C set of test tubes was kept at room temperature $\left(\approx 25^{\circ} \mathrm{C}\right)$. Both sets of test tubes were then incubated at $4{ }^{\circ} \mathrm{C}$ (kept in a refrigerator) for $24 \mathrm{~h}$. Initial conductance readings of both sets (CEC 1 and TEC 1) were performed using a bench electrical conductivity meter (Starter 3000C; Ohaus Corp., Parsippany, NJ) after bringing the test tubes to room temperature. The tubes were then sealed again with aluminum foil and autoclaved at $121{ }^{\circ} \mathrm{C}$ and $0.15 \mathrm{MPa}$ for $20 \mathrm{~min}$ to completely kill the leaf tissue. The autoclaved tubes were cooled to room temperature, the contents were mixed thoroughly, and a final conductance (CEC 2 and TEC 2) reading was taken. The CMT was calculated using the following equation, where TEC and CEC are a measure of conductance in the treated and control test tubes, respectively, for the initial (CEC 1 and TEC 1) and final (CEC 2 and TEC 2) conductance measurements (Gajanayake et al., 2011).

$$
\operatorname{CMT}(\%)=\frac{1-(\mathrm{TEC} 1 / \mathrm{TEC} 2)}{1-(\mathrm{CEC} 1 / \mathrm{CEC} 2)} \times 100
$$

Heat stress treatment. Seedlings were randomly divided into two groups, treated $\left(42^{\circ} \mathrm{C}\right)$ and control $\left(30^{\circ} \mathrm{C}\right)$, at 4 weeks after sowing. The plants were exposed to a gradual temperature increase $\left(10 \mathrm{~min}\right.$ for every $1^{\circ}$ increase) from 25 to $30{ }^{\circ} \mathrm{C}$ using an experimental plant growth chamber (GC-101C; Daeyang ${ }^{\text {ETS }}$, Hwasung-si, Kyunggi-do, South Korea). After the temperature reached $30{ }^{\circ} \mathrm{C}$, the plants were kept at $30{ }^{\circ} \mathrm{C}$ for $2 \mathrm{~h}$, and the same method of stress treatment was applied for extreme heat stress for $2 \mathrm{~h}$. After each stress treatment, leaf samples were harvested and immediately suspended in liquid nitrogen for subsequent analyses.

RNA EXTRACTION AND QUANTITATIVE REAL-TIME POLYMERASE CHAIN REACTION. Total RNA was extracted from each test sample using the Trizol method (Chomczynski and Sacchi, 1987). The RNA integrity was verified on a $1.5 \%$ agarose gel and using a spectrophotometer (Nanodrop 2000c; Thermo 
Fisher Scientific, Wilmington, DE). RNA with a 260/280 ratio of 1.8 to 2.0 was used for quantitative real-time polymerase chain reaction $(\mathrm{PCR})$. The primers used for the reactions were designed from the deduced sequence corresponding to HSP70 of tomato from the NCBI GenBank (accession no. NM 001247562.1) (Table 3). UBI-3 was used as a reference gene for normalization of the cDNA template quantity with previously published specific primers (Wan et al., 2011).

For each stress condition and the controls, expression measurements were performed using triplicate biological replications. Quantitative PCR was performed in $20-\mu \mathrm{L}$ reactions using gene-specific primers, $3 \mu \mathrm{L}$ of RNA template, and the
SYBR FAST One-Step qPCR Kit (Kapa Biosystems, Wilmington, MA). The reactions were performed using the CFX96 Real-Time PCR system (Bio-Rad, Mississauga, Ontario, Canada). The thermal profile for quantitative PCR was $5 \mathrm{~min}$ at $42{ }^{\circ} \mathrm{C}$ for cDNA synthesis, $3 \mathrm{~min}$ at $95^{\circ} \mathrm{C}$ followed by 40 cycles each consisting of $95{ }^{\circ} \mathrm{C}$ for $3 \mathrm{~s}$ and $60{ }^{\circ} \mathrm{C}$ for $30 \mathrm{~s}$. The primer specificity and the formation of primer-dimers were monitored by a dissociation curve analysis and agarose gel electrophoresis through a $1 \%$ agarose gel. The expression level of the pepper UBI-3 gene was used as an internal standard for the normalization of cDNA template quantity using specific primers (Table 3). Controls with no RNA template were also included

Table 1. List of Capsicum annuum genotypes used in this study of heat tolerance, including the source, pedigree, and heat tolerance.

\begin{tabular}{|c|c|c|c|c|}
\hline No. & Genotype $^{z}$ & Source & Pedigree & Heat tolerance $^{\mathrm{y}}$ \\
\hline 1 & AVPP9703 & CCA 1410A & HDA210/Szechwan10/MC4 & - \\
\hline 3 & AVPP0702 & CCA6023-9-1-1-2-1 & $\begin{array}{l}\text { Jin's Joy/4/Bangchang-selex/HDA210/ } \\
\text { Szechwan10/MC4 }\end{array}$ & Excellent \\
\hline 4 & AVPP0116 & CCA 3743 & PSP-11/Jin’s Delight/Kulai & Excellent \\
\hline 5 & AVPP0002 & CCA 3331 & Arunalu/Tumpang & Fair \\
\hline 6 & Kulai & Local & Cultivar cultivated in Malaysia & - \\
\hline
\end{tabular}

${ }^{\mathrm{z}} \mathrm{AV}=\mathrm{AVRDC}$ (The World Vegetable Center, Tainan, Taiwan); PP = pepper.

${ }^{y} A V R D C$, unpublished data.

Table 2. Morphological and physiological characteristics of Capsicum annuum measured in this study of heat tolerance.

\begin{tabular}{|c|c|}
\hline Characters & Description \\
\hline Plant height $(\mathrm{cm})$ & Taking from the surface of planting medium to the top of the plant \\
\hline Disease incidence $(\%)$ & $\begin{array}{l}\text { Percentage of infected leaves by mosaic virus to total number of leaves in three } \\
\text { random branches selected from each plant }\end{array}$ \\
\hline Fruit length $(\mathrm{cm})$ & The length of fruit from pedicel to tip of the fruit \\
\hline Fruit weight $(\mathrm{g})$ & The weight of individual fruit \\
\hline Number of fruit (no.) & Total number of fruits harvested from each plant \\
\hline Chlorophyll content $\left(\mu \mathrm{g} \cdot \mathrm{mL}^{-1}\right)$ & $\begin{array}{l}\text { Measurement of chlorophyll content was done following Coombs et al. } \\
\text { (1985) procedure }\end{array}$ \\
\hline Cell membrane thermostability & $\begin{array}{l}\text { The membrane stability was measured using the procedure described by } \\
\text { Gajanayake et al. (2011) }\end{array}$ \\
\hline
\end{tabular}

Table 3. Primer sequence $\left(5^{\prime}-3^{\prime}\right)$, amplicon length, efficiency (E), coefficient of determination $\left(R^{2}\right)$, and annealing temperature (Tm) of the target gene HSP70 and housekeeping gene UBI-3 analyzed in five AVRDC (The World Vegetable Center, Tainan, Taiwan) Capsicum annuum genotypes and one local Malaysian cultivar (Kulai) used for quantitative real-time polymerase chain reaction analysis.

\begin{tabular}{|c|c|c|c|c|c|c|}
\hline Gene & Gene symbol & Primer sequence $\left(5^{\prime}-3^{\prime}\right)^{\mathrm{z}}$ & $\begin{array}{l}\text { Amplicon } \\
\text { length (bp) }\end{array}$ & E & $R^{2}$ & $\operatorname{Tm}\left({ }^{\circ} \mathrm{C}\right)$ \\
\hline \multirow[t]{2}{*}{ Ubiquitin-conjugating protein } & UBI-3 & For TGTCCATCTGCTCTCTGTTG & 204 & 1.05 & 0.9989 & 54.4 \\
\hline & & Rev CACCCCAAGCACAATAAGAC & & & & 53.8 \\
\hline & & Rev ACATGAGAAACGCAGTGAAGG & & & & 55.4 \\
\hline
\end{tabular}

${ }^{\mathrm{z}}$ Forward (For) and reverse (Rev) primers. 
in the quantitative PCR analysis. The quantitative real-time PCR product was analyzed for molecular weight (MW) and HSP70 gene specificity using Kapa ${ }^{\mathrm{TM}}$ Universal Ladder (Kapa Biosystems) as a standard (Fig. 1) with a gel doc XR system (Bio-Rad). The MW was estimated using Image Laboratory software Version 5.0 provided by BioRad and ranged from 68 to $70 \mathrm{kDa}$.

Statistical Analysis. The data for membrane stability were subjected to a statistical analysis of variance, and the means were separated using Duncan's multiple range test with SAS (Version 9.2; SAS Institute, Cary, NC). The data analysis for HSP70 was performed using the software provided by Bio-Rad.

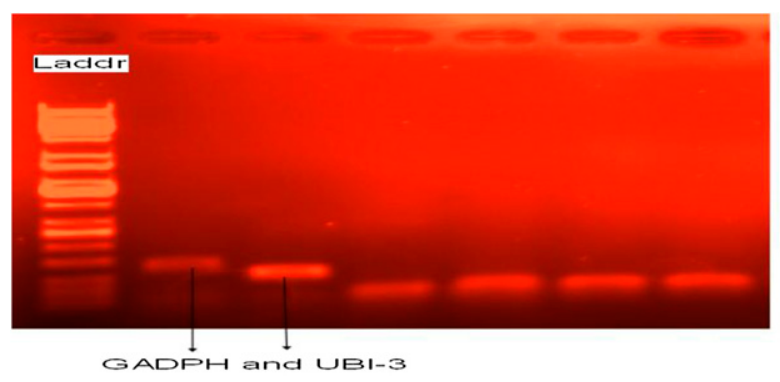

$70 \mathrm{kDa}$

Fig. 1. Gel electrophoresis showing the target HSP70 gene identified in Capsicum annuum. UBI-3 was used as the reference gene for normalization. The Kapa ${ }^{\mathrm{TM}}$ Universal Ladder [Laddr (Kapa Biosystems, Wilmington, MA)] was used as standard.
The comparative $\mathrm{Ct}\left(2^{-\Delta \Delta \mathrm{Ct}}\right)$ method was used to calculate the changes in gene expression as a relative fold difference between an experimental and calibrator sample. The genes that were upor down-regulated by more than 2 -fold $(P<0.05)$ were considered to be differentially expressed.

\section{Results and Discussion}

Field evaluation. The morphological, physiological, and biochemical characteristics of the studied genotypes were assessed and presented in Table 4.

Cell membrane thermostability. Electrical conductivity has been used as an index of membrane stability to identify heat-tolerant genotypes in chili (Gajanayake et al., 2011) and for screening heat-tolerant genotypes in different crops (Wahid et al., 2007). A highly significant $(P<0.05)$ difference was observed among the genotypes for CMT (Fig. 2). The heattolerant plants showed the highest CMT at $89.27 \%, 88.03 \%$, and $85.10 \%$ for AVPP0702, AVPP0116, and AVPP9905, respectively, which might explain the change in CMT. AVPP9703 exhibited $15.87 \%$, which might indicate its sensitivity to heat stress. According to Craufurd et al. (2003), CMT above $60 \%$ is heat-tolerant, $30 \%$ to $60 \%$ moderate, and less than $30 \%$ sensitive to heat stress with slight changes. The present investigation is in agreement with the works of Gajanayake et al. (2011), in which CMT was measured in 12 ornamental pepper genotypes, with most being thermotolerant, with a mean of $59.50 \%$. Similar results reported in wheat cultivars by

Table 4. Mean values of plant height at harvest, days to flowering (DF), disease incidence (DI), chlorophyll content (CPL), photosynthesis rate, fruit length (FL), fruit weight (FW), number of fruit, yield, and pungency level characteristics measured in the six studied genotypes of Capsicum annuum $(\mathrm{n}=3)$.

\begin{tabular}{|c|c|c|c|c|c|c|c|c|c|c|}
\hline Genotype & $\begin{array}{c}\text { Plant } \\
\text { ht }(\mathrm{cm})\end{array}$ & DF (d) & DI (\%) & $\begin{array}{c}\mathrm{CPL} \\
\left(\mu \mathrm{g} \cdot \mathrm{mL}^{-1}\right)\end{array}$ & $\begin{array}{l}\text { Photosynthesis } \\
\left(\mu \mathrm{mol} \cdot \mathrm{m}^{-2} \cdot \mathrm{s}^{-1}\right)\end{array}$ & $\mathrm{FL}(\mathrm{cm})$ & FW (g) & Fruit (no.) & $\begin{array}{c}\text { Yield } \\
\text { (g/plant) }\end{array}$ & $\begin{array}{l}\text { Pungency } \\
\left(^{(\text {SHU scale })^{z}}\right.\end{array}$ \\
\hline$\overline{\text { AVPP9703 }}$ & 60.60 & 63.00 & 31.25 & 5.64 & 14.28 & 10.79 & 9.08 & 49.33 & 338.08 & Non-pungent \\
\hline AVPP9905 & 68.27 & 62.67 & 41.24 & 5.57 & 12.74 & 16.43 & 22.94 & 63.00 & 1144.30 & Highly pungent \\
\hline AVPP0702 & 56.47 & 63.67 & 39.14 & 6.72 & 10.04 & 12.66 & 8.61 & 73.00 & 398.99 & Moderately pungent \\
\hline AVPP0002 & 60.23 & 62.83 & 40.79 & 6.30 & 10.92 & 9.09 & 3.29 & 208.33 & 490.44 & Very highly pungent \\
\hline AVPP0116 & 92.13 & 64.50 & 28.14 & 5.60 & 17.62 & 10.55 & 11.65 & 46.33 & 411.35 & Moderately pungent \\
\hline Kulai & 72.17 & 59.00 & 39.96 & 6.44 & 19.32 & 17.23 & 17.68 & 64.00 & 818.10 & Moderately pungent \\
\hline
\end{tabular}

${ }^{\mathrm{z} S c o v i l l e ~ h e a t ~ u n i t s . ~}$

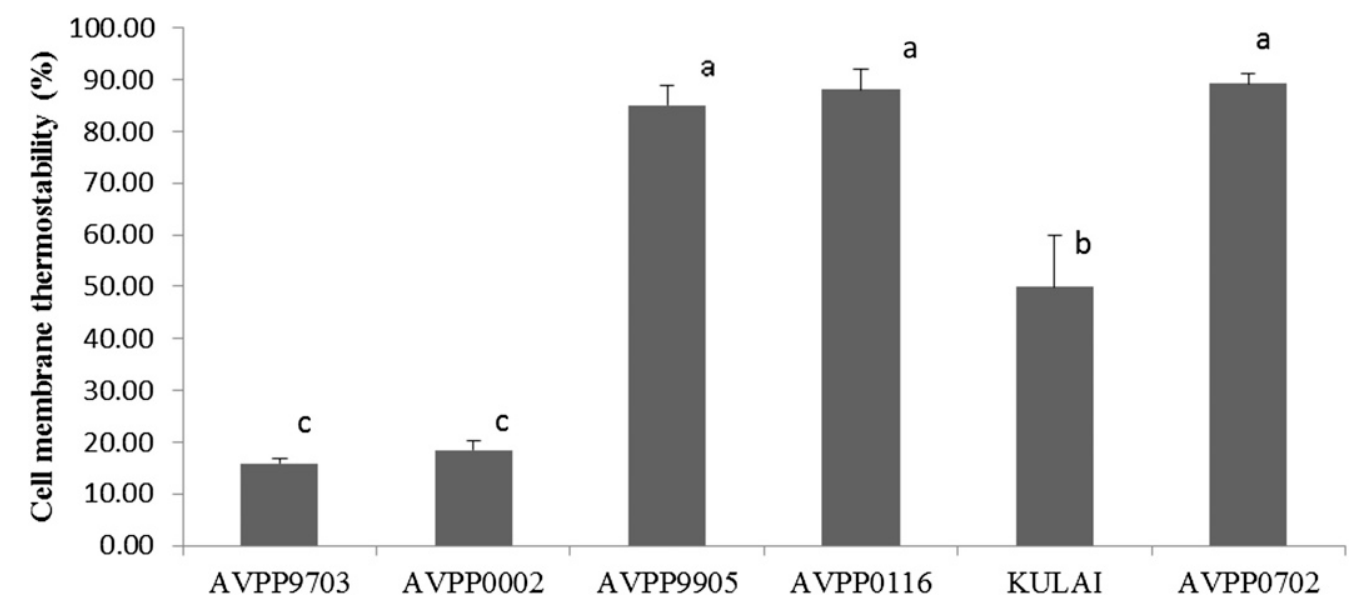

Fig. 2. Cell membrane stability index of Capsicum annuum genotypes, each bar showing the stability of the membrane on exposure to heat stress; bars followed by the same letters are not statistically significant $(P<0.05)$ using Duncan's multiple range test. Error bars indicate $\mathrm{SE}(\mathrm{n}=3)$. 
Kumar et al. (2012) with indications of changes in membrane stability against heat stress.

The mean value of CMT of the genotypes from this investigation indicates that the membrane integrity of the heattolerant genotypes was not damaged by the high-temperature treatment of $50{ }^{\circ} \mathrm{C}$ for $20 \mathrm{~min}$, whereas AVPP9703 and AVPP0002 were sensitive and damaged at $50{ }^{\circ} \mathrm{C}$. The membrane is the first line of defense with many heat-responsive sensors that help plants to activate defense mechanisms early in heat shock (Singh et al., 2007). The unification and roles of cell membranes are sensitive to high-temperature stress. Indeed, heat stress alters the post-secondary structures of membrane proteins, and the permeability of electrolytes increases as a result of such changes. Increased electrolyte leakage indicates decreased CMT, which has long been used as an indirect mechanism of heat stress tolerance in several crop plant species, including tomato (Islam et al., 2014), potato [Solanum tuberosum (Nagarajan and Bansal, 1986)], and wheat (Kumar et al., 2012).

Amplification and identification of the HSP70 target GENE. A known-specific $H S P 70$ primer of tomato was used as a template to examine its presence in the candidate chili peppers. Strong positive threshold cycle (Cq less than 29) values were observed in all genotypes, indicative of abundant target nucleic acid in the samples, except for 'Kulai', which showed a weak reaction (Cq of 38 to 40 ) indicative of a minimal amount of the target nucleic acid in the sample (Table 5). Heat stress is known to trigger changes in the transcription of HSP genes. Therefore, we assessed the expression profile of the HSP70 gene under heat stress using quantitative real-time PCR. The $\mathrm{Cq}$ is defined as the number of cycles required for the fluorescent signal to exceed the background level, and threshold cycles are inversely proportional to the quantity of target nucleic acid in the sample: the lower the Cq level, the greater the quantity of target nucleic acid in the sample. The real-time assays used 40 cycles of amplification, and all genotypes showed abundant target nucleic acid in leaf tissues under heat stress, except for 'Kulai', which showed a minimal amount of the target gene. Under heat stress, significantly increased levels of the HSP 70 gene were detected after $2 \mathrm{~h}$ of temperature treatment at $42{ }^{\circ} \mathrm{C}$, which indicated that this gene is quickly and sharply induced by heat shock. This was true for all genotypes, which were significantly up-regulated by more than 36.9-, 7.10-, 3.87-, and 3-fold for AVPP0702, AVPP0116, AVPP0002, and AVPP9703, respectively (Table 5). In contrast, 'Kulai' showed significant HSP70 down-regulation under heat stress (Table 5).

ANALYSIS OF FOLD DIFFERENCES IN HSP70 GENE EXPRESSION UNDER HEAT STRESS. The genes that were up- or down-regulated by more than 2 -fold and with $P<0.05$ were considered to be differentially expressed. AVPP0702, AVPP0116, and AVPP9703 in this study showed differential expression: HSP70 was up-regulated by 36.8-, 7.1-, and 2.58-fold in AVPP0702, AVPP0116, and AVPP9703 with $P<0.05$, respectively (Fig. 3). The up-regulation of HSP70 in AVPP0702, AVPP9905, AVPP0116, and AVPP9703 indicates that HSP70 increases in the cell when exposed to heat stress; the downregulation of HSP70 in 'Kulai' indicates the opposite.

From this present investigation, genotypes having a high CMT appear to have high expression of $H S P 70$, which might indicate thermotolerance. AVPP0702, AVPP9905, and AVPP0116 could be considered as heat-tolerant genotypes, whereas 'Kulai' and AVPP9703 can be considered as heatsensitive genotypes. A deficiency in the expression of chaperones often results in increased thermosensitivity or death, even under normal growth conditions (Chen et al., 1982). The expression of HSP70 in thermotolerant genotypes is higher than thermosensitive genotypes, indicating better protection against heat shock stress. A significant positive correlation between $H S P 70$ gene expression and the acquisition of thermotolerance has been studied by Lee et al. (2009), resulting in increased tolerance to water and high-temperature stress in plants (Alvim et al., 2001; Ono et al., 2001; Sung and Guy, 2003). Thus, AVPP0702, AVPP9905, and AVPP0116 have better protection against heat stress than AVPP9703 and 'Kulai'. The works of Ferguson et al. (1990) showed that membrane stability and HSP70 accumulation is higher in heattolerant chilean mesquite (Prosopis chilensis) than heat-susceptible soybean (Glycine max) at 20 min of treatment at $40{ }^{\circ} \mathrm{C}$ as well as after 60 and 90 min of heat shock.

FUNCTION OF HSP70 GENE UNDER HEAT STRESS. Heat stress is one of the abiotic factors that cause the most severe damage to crop plants. In nature, individual stresses such as drought and high temperature usually do not occur separately. Two major

Table 5. Descriptive information of the target gene HSP70 for each of the six Capsicum annuum genotypes as revealed by quantitative real-time polymerase chain reaction analysis. ${ }^{z}$

\begin{tabular}{|c|c|c|c|c|c|c|c|}
\hline Genotype & $\begin{array}{c}\text { Mean } \\
\mathrm{Cq}^{\mathrm{y}}\end{array}$ & $\begin{array}{c}\text { Mean efficiency } \\
\text { corrected } \mathrm{Cq}\end{array}$ & $\begin{array}{l}\text { Normalized } \\
\text { expression }^{\mathrm{x}}\end{array}$ & $\begin{array}{l}\text { Relative normalized } \\
\text { expression }^{\mathrm{w}}\end{array}$ & Regulation & $\begin{array}{l}\text { Compared with } \\
\text { regulation threshold }\end{array}$ & $P$ value \\
\hline AVPP0702 & 23.38 & 22.89 & 3.93 & 36.86 & 36.86 & Up-regulated & 0.000039 \\
\hline AVPP9905 & 26.38 & 25.83 & 0.41 & 15.10 & 15.10 & Up-regulated & - \\
\hline AVPP0002 & 25.5 & 24.96 & 0.30 & 3.87 & 3.87 & Up-regulated & 0.129202 \\
\hline AVPP9703 & 24.02 & 23.52 & 6.33 & 2.58 & 2.58 & Up-regulated & 0.001436 \\
\hline Kulai & 38.03 & 37.23 & 0.00028 & 0.06 & -17.38 & Down-regulated & 0.000404 \\
\hline
\end{tabular}

${ }^{\mathrm{z}}$ Analysis of the $H S P 70$ under heat stress $\left(42^{\circ} \mathrm{C}\right)$ includes amplification efficiency $(\mathrm{Cq})$, normalized and relative normalized expression, gene regulation, and probability value.

${ }^{y}$ Cycle threshold $(\mathrm{Cq})$ indicates the abundance of the target nucleic acid; the lower the Cq level, the higher the nucleic acid (in this case HSP70).

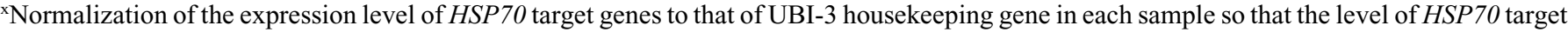
gene in one sample can be compared with another. This normalization process controls for unequal RNA loading, differences introduced during $\mathrm{RT}$ reaction, etc.

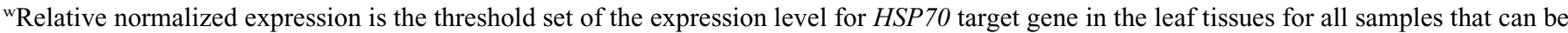
used to know whether the gene expresses higher in the stressed plants than in the normal plants. 


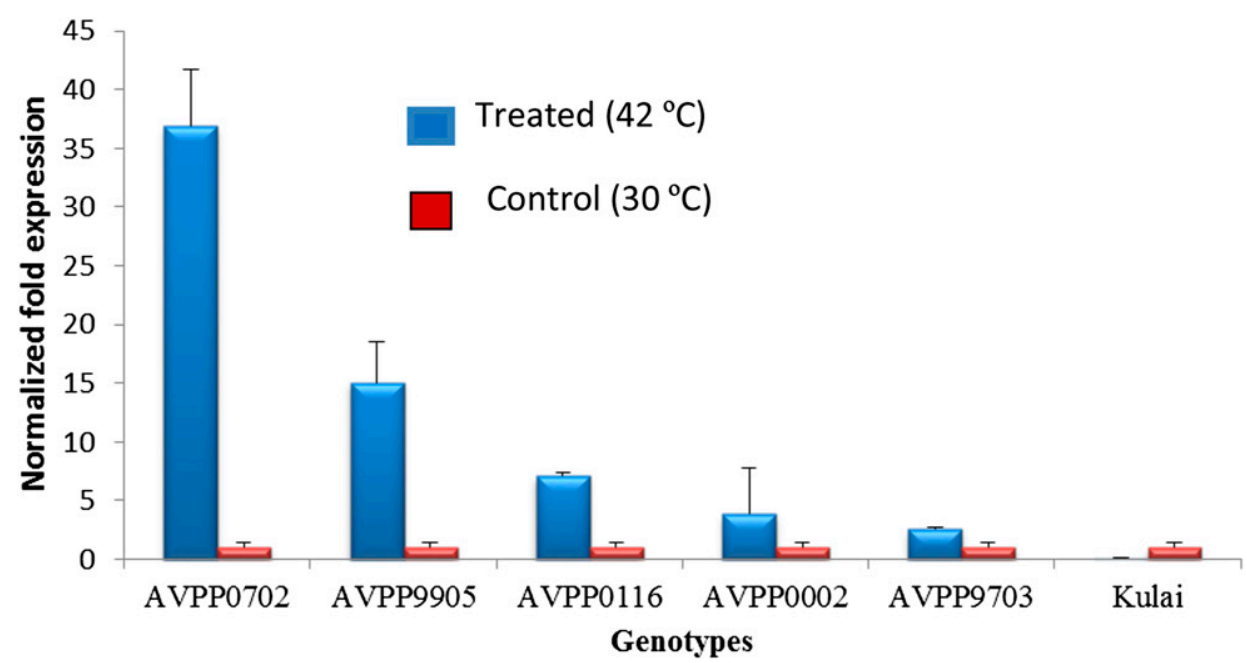

Fig. 3. Change in the expression level of HSP70 gene in AVPP0702, AVPP0116, and AVPP9905 (tolerant) and AVPP9703 and 'Kulai' (sensitive) Capsicum annuum genotypes under heat shock treatment of 30 and $42{ }^{\circ} \mathrm{C}$ for 2 h. UBI-3 was used as endogenous control. Error bars indicate SE $(n=3)$.

factors that lead to an increased respiration rate, the closure of the stomata, reduced photosynthesis rates, and increased leaf temperature in plants are heat shock and drought (Ye et al., 2012). To counter the effects of such stress, plants express a variety of defense genes such as HSPs (Ye et al., 2012). The transcription level of all HSP70 genes in this study was significantly enhanced under heat stress in the heat-tolerant genotypes, which showed that this gene may play a role in heat stress responses.

The synthesis and accumulation of specific proteins are established during rapid heat stress, and these proteins are described as HSPs. Many studies maintain that HSPs are molecular chaperones protecting the native arrangement of cellular proteins under heat stress. Among these, HSP70 is one of the most abundant HSPs in eukaryotic cells. HSP70 binds in an ATP-dependent manner to hydrophobic patches of partially unfolded proteins and prevents protein aggregation (Mayer and Bukau, 2005). Although HSP70s accumulate during heat shock, their constitutively expressed cognates (HSC70) are essential for general cellular functions as a result of their involvement in the control of protein homeostasis. They assist in the folding of nascent polypeptides released from the ribosome (Hartl and Hayer-Hartl, 2002), sorting of proteins to cellular organelles by interaction with mitochondrial and chloroplast protein import complexes (Mirus and Schleiff, 2009; Zhang and Glaser, 2002), and form a link with the ubiquitin-mediated proteasomal degradation pathway (Ballinge et al., 1991; Lüders et al., 2000).

\section{Conclusion}

Terminal heat stress leads to changes in the various parameters such as HSP genes and CMT in chili pepper and is an important component of thermotolerance capacity. Altered CMT values were also observed with differential heat shock. An abundance of HSP70 gene transcript was observed in leaf tissues in the heat-tolerant genotypes compared with the heat-susceptible genotype; genotypes having a high CMT appear to have high $H S P 70$ expression, which might indicate thermotolerance. Despite the upregulation of $H S P 70$ gene in AVPP0002 and AVPP9703, the expression levels were found to be very low and hence might indicate sensitivity to heat stress. The reason behind down-regulation/up-regulation is that the cellular components decrease or increase in response to external variables such as heat stress. The extent of differences observed in HSP70 and membrane stability can be used to improve thermotolerance capacity among the studied genotypes. For further chili breeding improvement program, this might also help chili breeders breeding for abiotic stress. The further analysis of HSP70 promoter elements may lead to a better understanding of the regulatory mechanisms controlling the tissuespecific expression of the HSP70 gene for use in enhancing the thermotolerance capacity of plants.

\section{Literature Cited}

Acedo, A.L., Jr. 2010. Postharvest technology for fresh chili pepper in Cambodia, Laos, and Vietnam. AVRDC Publ. No. 10-735.

Ahmed, J. and M. Hassan. 2011. Evaluation of seedling proline content of wheat genotypes in relation to heat tolerance. Bangladesh J. Bot. 40:17-22.

Ajjapplavara, P.S., S.S. Patil, R.M. Hosamani, A.A. Patil, and S. Gangaprasad. 2010. Correlation and path coefficient analysis in chilli. Karnataka J. Agr. Sci. 18:748-751.

Alvim, F.C., S.M. Carolino, J.C. Cascardo, C.C. Nunes, C.A. Martinez, W.C. Otoni, and E.P. Fontes. 2001. Enhanced accumulation of BiP in transgenic plants confers tolerance to water stress. Plant Physiol. 126:1042-1054.

Ballinge, C.A., P. Connell, Y. Wu, Z. Hu, L.J. Thompson, L. Yin, and C. Patterson. 1991. Identification of CHIP, a novel tetratricopeptide repeat-containing protein that interacts with heat shock proteins and negatively regulates chaperone functions. Mol. Cell. Biol. 19:4535-4545.

Bukau, B., J. Weissman, and A. Horwich. 2006. Molecular chaperones and protein quality control. Cell 125:443-451.

Chen, H., Z. Shen, and P. Li. 1982. Adaptability of crop plants to high temperatures stress. Crop Sci. 22:719-725.

Chomczynski, P. and N. Sacchi. 1987. Single-step method of RNA isolation by acid guanidinium thiocyanate-phenol-chloroform extraction. Anal. Biochem. 162:156-159.

Collins, M.D., L.M. Wasmund, and P.W. Bosland. 1995. Improved method for quantifying capsaicinoids in capsicum using highperformance liquid chromatography. HortScience 30:137-139.

Coombs, J., G. Hind, R. Leegood, L. Tieszen, and A. Vonshak. 1985. Analytical techniques. Tech. Bioproductivity Photosyn. 2:219-228.

Craufurd, P., P.V. Prasad, V. Kakani, T. Wheeler, and S. Nigam. 2003. Heat tolerance in groundnut. Field Crops Res. 80:63-77.

Dahal, K., M. Sharma, D. Dhakal, and S. Shakya. 2006. Evaluation of heat tolerant chilli (Capsicum annuum L.) genotypes in Western Terai of Nepal. J. Inst. Agr. Animal Sci. 27:59-64.

Duan, Y.H., J. Guo, K. Ding, S.J. Wang, H. Zhang, X.W. Dai, Y.Y. Chen, F. Govers, L.L. Huang, and Z.S. Kang. 2011. Characterization of a wheat HSP70 gene and its expression in response to stripe rust infection and abiotic stresses. Mol. Biol. Rpt. 38:301-307.

Efeoğlu, B. 2009. Heat shock proteins and heat shock response in plants. Gazi Univ. J. Sci. 22:67-75. 
Fender, S.E. and M.A. O'Connell. 1989. Heat shock protein expression in thermotolerant and thermo-sensitive lines of cotton. Plant Cell Rpt. 8:37-40.

Ferguson, D.L., J.A. Guikema, and G.M. Paulsen. 1990. Ubiquitin pool modulation and protein degradation in wheat roots during high temperature stress. Plant Physiol. 92:740-746.

Gajanayake, B., B.W. Trader, K.R. Reddy, and R.L. Harkess. 2011. Screening ornamental pepper cultivars for temperature tolerance using pollen and physiological parameters. HortScience 46:878-884.

Hall, A.E. 2010. Crop responses to environment. CRC Press, Boca Raton, FL.

Hartl, F.U. and M. Hayer-Hartl. 2002. Molecular chaperones in the cytosol: From nascent chain to folded protein. Science 295:18521858.

Hightower, L.E. 1991. Heat shock, stress proteins, chaperones, and proteotoxicity. Cell 66:191-197.

Islam, M.S., S. Ahmad, M.N. Uddin, M.Y. Rafii, M.R. Ismail, and M.A. Malek. 2014. Identification of tomato inbred lines for heat tolerance through agronomic and physiological approaches. J. Food Agr. Environ. 12:281-284.

Jones, P.D., M. New, D.E. Parker, S. Martin, and I.G. Rigor. 1999. Surface air temperature and its changes over the past 150 years. Rev. Geophys. 37:173-199.

Knight, C.A. 2010. Small heat shock protein responses differ between chaparral shrubs from contrasting microclimates. J. Bot. Article 171435. DOI: 10.1155/2010/171435.

Kumar, R.R., S. Goswami, S.K. Sharma, K. Gadpayle, N. Kumar, G.K. Rai, M. Singh, and R.D. Rai. 2012. Protection against heat stress in wheat involves change in cell membrane stability, antioxidant enzymes, osmolyte, $\mathrm{H} 2 \mathrm{O} 2$ and transcript of heat shock protein. Intl. J. Plant Physiol. Biochem. 4:83-91.

Kuwabara, C. and R. Imai. 2009. Molecular basis of disease resistance acquired through cold acclimation in overwintering plants. J. Plant Biol. 52:19-26.

Lee, J.H. and F. Schöffl. 1996. An HSP70 antisense gene affects the expression of HSP70/HSC70, the regulation of HSF, and the acquisition of thermotolerance in transgenic Arabidopsis thaliana. Mol. Gen. Genet. 252:11-19.

Lee, S., D.W. Lee, Y. Lee, U. Mayer, Y. Stierhof, S. Lee, G. Jürgens, and I. Hwang. 2009. Heat shock protein cognate 70-4 and an E3 ubiquitin ligase, CHIP, mediate plastid-destined precursor degradation through the ubiquitin-26S proteasome system in arabidopsis. Plant Cell Online 21:3984-4001.

Lindquist, S. 1986. The heat-shock response. Annu. Rev. Biochem. 55:1151-1191.

Lüders, J., J. Demand, and J. Höhfeld. 2000. The ubiquitin-related BAG-1 provides a link between the molecular chaperones Hsc70/ Hsp70 and the proteasome. J. Biol. Chem. 275:4613-4617.

Mayer, M. and B. Bukau. 2005. Hsp70 chaperones: Cellular functions and molecular mechanism. Cell. Mol. Life Sci. 62:670-684.

Mirus, O. and E. Schleiff. 2009. The evolution of tetratricopeptide repeat domain containing receptors involved in protein translocation. Endocytobiosis Cell Res. 19:31-50.
Nagarajan, S. and K.C. Bansal. 1986. Measurement of cellular membrane thermostability to evaluate foliage heat tolerance of potato. Potato Res. 29:163-167.

Ono, K., T. Hibino, T. Kohinata, S. Suzuki, Y. Tanaka, T. Nakamura, T. Takabe, and T. Takabe. 2001. Overexpression of DnaK from a halotolerant cyanobacterium (Aphanothece halophytica) enhances the high-temperature tolerance of tobacco during germination and early growth. Plant Sci. 160:455-461.

Ortiz, C. and L. Cardemil. 2001. Heat-shock responses in two leguminous plants: A comparative study. J. Expt. Bot. 52:1711-1719.

Pratt, W.B., P. Krishna, and L.J. Olsen. 2001. Hsp90-binding immunophilins in plants: The protein movers. Trends Plant Sci. 6:54-58.

Singh, R.P., P. Prasad, K. Sunita, S. Giri, and K.R. Reddy. 2007. Influence of high temperature and breeding for heat tolerance in cotton: A review. Advance Agron. 93:313-385.

Sood, S., R. Sood, V. Sagar, and K. Sharma. 2009. Genetic variation and association analysis for fruit yield, agronomic and quality characters in bell pepper. Intl. J. Veg. Sci. 15:272-284.

Sung, D.Y. and C.L. Guy. 2003. Physiological and molecular assessment of altered expression of Hsc70-1 in Arabidopsis. Evidence for pleiotropic consequences. Plant Physiol. 132:979-987.

Suzuki, N. and R. Mittler. 2006. Reactive oxygen species and temperature stresses: A delicate balance between signaling and destruction. Physiol. Plant. 126:45-51.

Usman, M.G., M.Y. Rafii, M.R. Ismail, M.A. Malek, and M. Abdul Latif. 2014a. Heritability and genetic advance among chili pepper genotypes for heat tolerance and morphophysiological characteristics. Sci. World J. Article 308042. DOI: 10.1155/2014/308042.

Usman, M.G., M.Y. Rafii, M.R. Ismail, M.A. Malek, and M.A. Latif. 2014b. Capsaicin and dihydrocapsaicin determination in chili pepper genotypes using ultra-fast liquid chromatography. Molecules 19:6474-6488.

Wahid, A., S. Gelani, M. Ashraf, and M. Foolad. 2007. Heat tolerance in plants: An overview. Environ. Exp. Bot. 61:199-223.

Wan, H., W. Yuan, M. Ruan, Q. Ye, R. Wang, L. Zhimiao, Z. Gouzhi, and Y. Yang. 2011. Identification of reference genes for reverse transcription quantitative real-time PCR normalization in pepper (Capsicum annuum). Biochem. Biophys. Res. Commun. 416:24-30.

Wang, W., B. Vinocur, O. Shoseyov, and A. Altman. 2004. Role of plant heat-shock proteins and molecular chaperones in the abiotic stress response. Trends Plant Sci. 9:244-252.

Weiss, E.A. 2002. Spice crops. CABI, New York, NY.

Ye, S., S. Yu, L. Shu, J. Wu, A. Wu, and L. Luo. 2012. Expression profile analysis of 9 heat shock protein genes throughout the life cycle and under abiotic stress in rice. Chin. Sci. Bull. 57:336-343.

Yeh, D. and P. Hsu. 2004. Heat tolerance in English ivy as measured by an electrolyte leakage technique. J. Hort. Sci. Biotechnol. 79:298302.

Young, J.C. 2010. Mechanisms of the Hsp70 chaperone system. Biochem. Cell Biol. 88:291-300.

Zhang, X. and E. Glaser. 2002. Interaction of plant mitochondrial and chloroplast signal peptides with the Hsp70 molecular chaperone. Trends Plant Sci. 7:14-21. 